\title{
biomolecules
}

ISSN 2218-273X

www.mdpi.com/journal/biomolecules/

Review

\section{Alcoholic Liver Disease: Role of Cytokines}

Manuela G. Neuman ${ }^{1,2, *}$, Yaakov Maor ${ }^{3}$, Radu M. Nanau ${ }^{1}$, Ehud Melzer ${ }^{3}$, Haim Mell ${ }^{4}$, Mihai Opris ${ }^{1,5}$, Lawrence Cohen ${ }^{6}$ and Stephen Malnick ${ }^{3}$

1 In Vitro Drug Safety and Biotechnology, University of Toronto, Toronto, ON M5G 0A3, Canada; E-Mails: radu.nanau@utoronto.ca (R.M.N.); M_neuman@rogers.com (M.O.)

2 Department of Pharmacology and Toxicology, Faculty of Medicine, University of Toronto, Toronto, ON M5G 0A3, Canada

3 Division of Gastroenterology, Kaplan Health Sciences Centre, Department of Medicine, Faculty of Medicine, Hebrew University, Rehovot 76100, Israel; E-Mails: halishy@netvision.net.il (Y.M.); ehudm@clalit.org.il (E.M.); stephen@malnick.net (S.M.)

4 Israel Anti-Drug Authority, Jerusalem 91039, Israel; E-Mail: haimm@antidrugs.gov.il

5 Casa de Ajutor Reciproc, Bucharest 031621, Romania

6 Sunnybrook Health Sciences Centre and Department of Internal Medicine, University of Toronto, Toronto, ON M5G 0A3, Canada; E-Mail: lawrence.cohen@sunnybrook.ca

* Author to whom correspondence should be addressed; E-Mail: manuela.neuman@utoronto.ca; Tel.: +1-416-398-4880.

Academic Editors: Natalia Osna and Kusum Kharbanda

Received: 3 July 2015 / Accepted: 24 August 2015 / Published: 28 August 2015

Abstract: The present review spans a broad spectrum of topics dealing with alcoholic liver disease (ALD), including clinical and translational research. It focuses on the role of the immune system and the signaling pathways of cytokines in the pathogenesis of ALD. An additional factor that contributes to the pathogenesis of ALD is lipopolysaccharide (LPS), which plays a central role in the induction of steatosis, inflammation, and fibrosis in the liver. LPS derived from the intestinal microbiota enters the portal circulation, and is recognized by macrophages (Kupffer cells) and hepatocytes. In individuals with ALD, excessive levels of LPS in the liver affect immune, parenchymal, and non-immune cells, which in turn release various inflammatory cytokines and recruit neutrophils and other inflammatory cells. In this review, we elucidate the mechanisms by which alcohol contributes to the activation of Kupffer cells and the inflammatory cascade. The role of the stellate cells in fibrogenesis is also discussed. 
Keywords: alcoholic liver disease; hepatocellular carcinoma; lipopolysaccharide; transforming growth factor; Toll-like receptor; tumor necrosis factor

\section{Introduction}

The clinical spectrum of alcoholic liver disease (ALD) includes the accumulation of lipids (steatosis), in the presence or absence of inflammation (steatohepatitis), leading to cirrhosis and an increased risk of hepatocellular carcinoma (HCC) [1]. The mechanism of alcohol-induced hepatotoxicity comprises interactions between the direct toxic effects of alcohol and its metabolites on various cell types in the liver, induction of reactive oxygen species, up-regulation of the inflammatory cascade, as well as other cell-specific effects in the liver [2-4]. The histological stages of ALD include fatty liver or simple steatosis, alcoholic hepatitis ( $\mathrm{AH}$ ), and chronic hepatitis that may also be associated with the presence of Mallory's hyaline, megamitochondria, or perivenular and perisinusoidal fibrosis [5,6]. Fatty liver develops in approximately $90 \%$ of individuals who drink more than $60 \mathrm{~g}$ alcohol/day. This condition is completely reversible after 4-6 weeks of abstinence, even if fibrosis has already developed [1,7].

The most worrisome feature in liver disease is hepatic fibrosis, which represents the liver's wound healing response to alcohol-induced injury. Hepatic fibrosis is characterized by the accumulation of interstitial matrix [8,9]. Liver fibrosis results from the activation of hepatic stellate cells. Stellate cells activation is a phenotype transition whose effect is the formation of collagen deposits. Features of stellate cell activation include increased cell accumulation, increased matrix production, enhanced contractility, diminished degradation of the extracellular matrix, release of pro-fibrogenic cytokines, and loss of cellular vitamin A. Alcohol may enhance fibrogenesis through stimulation of stellate cells, generation of lipid peroxides from damaged hepatocytes, metabolic production of toxic acetaldehyde that induces direct fibrogenic activity, and through the activation of Kupffer cells or resident macrophages [10].

\section{Alcohol and Cytokines}

Cytokines are inflammatory mediators that serve important roles in the pathogenesis of many acute and chronic diseases, including alcoholic liver disease [2-4]. A wide range of cytokines were assessed in samples of ALD patients. These include tumor necrosis factor (TNF)- $\alpha$, various interleukins (IL) such as IL-1 $\beta$, IL-4, IL-6, IL-10, and IL-12, and interferon (IFN)- $\gamma$, as well as high-sensitivity C-reactive protein (hsCRP), as described in Table 1 [11-21]. Several studies have uncovered relationships between cytokine levels and the severity of the disease, as well as the presence of co-morbidities. Mean IL-6, IL-8, hsCRP, and TNF- $\alpha$ levels were higher among individuals with more advanced liver disease [16,17]. TNF- $\alpha$ and IL- 6 levels could be used to differentiate between patients with compensated cirrhosis and patients with de-compensated alcoholic cirrhosis [21]. Elevated levels of soluble TNF-receptor 55 and soluble IL-2 receptor were associated with bone resorption (deoxypyridinoline urinary excretion) and osteoporosis in patients with alcohol-induced cirrhosis [18]. Elevated IL-6 [hazard ratio (HR) 2.94, 95\% confidence interval (CI) 1.69-5.12, $p<0.01$ ) and CRP (HR 1.87, 95\% CI 1.11-3.15, $p=0.02$ ) 
levels were associated with mortality in a large cohort of human immunodeficiency virus-infected adults with alcohol problems [12].

Table 1 summarizes levels of pro-inflammatory markers in ALD patients [11-21].

Table 1. Cytokine and pro-inflammatory markers levels in alcoholic liver disease patients. AH: alcoholic hepatitis; ALD: alcoholic liver disease; CSF: cerebrospinal fluid; hsCRP: high-sensitivity C-reactive protein; IFN: interferon; IL: interleukin; IQR: interquartile range; MCP: monocyte chemoattractant protein; sIL-2R: soluble IL-2 receptor; sTNF-R55: soluble tumor necrosis factor receptor 55; TGF: transforming growth factor; TNF: tumor necrosis factor; VEGF: vascular endothelial factor.

\begin{tabular}{|c|c|c|}
\hline Refs. & Population/Matrix & Findings: Mean \pm Standard Deviation or Median (IQR); \\
\hline \multirow{2}{*}{ [11] } & 28 alcoholics, & MCP-1 (pg/mL): Healthy controls 425.7; Alcoholics $455.9(p=0.001)$ \\
\hline & 13 controls/CFS & IL-1 $\beta$ : no difference \\
\hline \multirow{7}{*}{ [12] } & \multirow{7}{*}{$\begin{array}{l}400 \text { human immunodeficiency } \\
\text { virus-infected adults with } \\
\text { alcohol problems followed } \\
\text { prospectively/serum }\end{array}$} & IL-6 (pg/mL): 2.75 (IQR 1.52-4.81) \\
\hline & & IL-10 (pg/mL): 5.03 (IQR 3.08-8.20) \\
\hline & & TNF- $\alpha(\mathrm{pg} / \mathrm{mL}): 7.15$ (IQR 4.85-9.70) \\
\hline & & CRP (mg/mL): 1.48 (IQR 0.60-3.47) \\
\hline & & Cystatin-C (ng/mL): 0.77 (IQR 0.67-0.91) \\
\hline & & MCP-1 (pg/mL): 577 (IQR 397-815) \\
\hline & & Amyloid A (mg/mL): $3.2(1.8-6.4)$ \\
\hline \multirow{3}{*}{ [13] } & \multirow{3}{*}{$\begin{array}{l}50 \text { cirrhotic patients }(60 \% \text { of } \\
\text { alcoholic etiology }) / \text { serum }\end{array}$} & $\mathrm{CRP}(\mathrm{mg} / \mathrm{dL}): 0.53 \pm 0.21$ \\
\hline & & Lipopolysaccharide-binding protein $(\mathrm{ng} / \mathrm{mL}): 8669 \pm 1207$ \\
\hline & & IL-6 (pg/mL): $6.94 \pm 3.43$ \\
\hline \multirow{6}{*}{ [14] } & \multirow{6}{*}{$\begin{array}{l}47 \text { ALD ( } 31 \text { non-cirrhotic } \\
\text { and } 16 \text { cirrhotic), } 18 \text { controls; } \\
\text { in serum }\end{array}$} & TNF- $\alpha(\mathrm{pg} / \mathrm{mL})$ : Controls $6.12 \pm 1.87$; ALD Non-cirrhotic: $5.013 \pm 2.10$; ALD Cirrhotic: $7.18 \pm 3.51$ \\
\hline & & IL-4 (ng/mL): Controls $4.62 \pm 6.17$; ALD Non-cirrhotic: $0.82 \pm 1.53$; ALD Cirrhotic: $1.89 \pm 4.57$ \\
\hline & & IL-6 (pg/mL): Controls $5.94 \pm 1.68$; ALD Non-cirrhotic: $6.46 \pm 4.87$; ALD Cirrhotic: $7.79 \pm 9.11$ \\
\hline & & IL-10 (pg/mL): Controls $9.00 \pm 12.10$; ALD Non-cirrhotic: $11.67 \pm 24.92$; ALD Cirrhotic: $11.71 \pm 8.21$ \\
\hline & & IL-13 (pg/mL): Controls $4.06 \pm 6.60$; ALD Non-cirrhotic: $10.67 \pm 19.90$; ALD Cirrhotic: $26.42 \pm 32.49$ \\
\hline & & IFN- $\gamma(\mathrm{pg} / \mathrm{mL})$ : Controls $0.7 \pm 0.51$; ALD Non-cirrhotic: $6.75 \pm 7.64$; ALD Cirrhotic: $4.23 \pm 2.58$ \\
\hline \multirow{13}{*}{ [15] } & \multirow{13}{*}{$\begin{array}{l}56 \mathrm{AH} \text { patients, } 18 \text { age- and } \\
\text { sex-matched controls/serum }\end{array}$} & $\mathrm{CRP}(\mathrm{mg} / \mathrm{mL})$ : Controls $0.36 \pm 1.11$; AH day 0: $3.68 \pm 6.09(p<0.001)$; AH day 15: $1.34 \pm 1.87(p<0.001)$ \\
\hline & & IL-8 (pg/mL): Controls $6.75 \pm 1.79 ;$ AH day 0: $57.80 \pm 97.05(p<0.005 v s$. control $)$ \\
\hline & & AH day $15: 26.60 \pm 35.15(p<0.005 v s$. control $)$ \\
\hline & & IL-10 (pmol/L): Controls $8.22 \pm 10.69 ;$ AH day $0: 5.13 \pm 0.59(p<0.001 v s$. control); \\
\hline & & AH day $15: 5.90 \pm 4.10(p<0.001 v s$. control $)$ \\
\hline & & IL-4 (ng/mL): Controls $2.28 \pm 1.72 ;$ AH day 0: $6.88 \pm 10.20$ ( $p<0.05 v s$. control); \\
\hline & & AH day $15: 27.49 \pm 42.90(p<0.05 v s$. control $)$ \\
\hline & & IFN- $\gamma(\mathrm{pg} / \mathrm{mL})$ : Controls $0.66 \pm 0.50 ;$ AH day $0: 4.74 \pm 12.60(p<0.05 v s$. control $)$ \\
\hline & & AH day $15: 2.94 \pm 3.68(p<0.05 v s$. control $)$ \\
\hline & & TNF- $\alpha(\mathrm{pg} / \mathrm{mL}):$ Controls $5.83 \pm 1.77$; AH day $0: 7.22 \pm 7.21$; AH day $15: 6.97 \pm 3.84$ \\
\hline & & IL-6 (pg/mL): Controls $5.77 \pm 1.40 ;$ AH day 0: $39.82 \pm 81.85 ;$ AH day $15: 11.87 \pm 21.38$ \\
\hline & & Malondialdehyde: Controls $1.31 \pm 0.69$; AH day $0: 8.34 \pm 6.76(p<0.001 v s$. control); \\
\hline & & AH day $15: 7.16 \pm 5.38(p<0.001 v s$. control $)$ \\
\hline
\end{tabular}


Table 1. Cont.

\begin{tabular}{|c|c|c|}
\hline Refs. & Population/Matrix & Findings: Mean \pm Standard Deviation or Median (IQR); \\
\hline [16] & $\begin{array}{l}45 \text { stable patients with } \\
\text { alcoholic cirrhosis ( } 16 \text { with } \\
\text { Child A stage, } 19 \text { with } \\
\text { Child B stage and } 10 \text { with } \\
\text { Child C stage), } 12 \text { healthy } \\
\text { controls; in serum }\end{array}$ & $\begin{array}{l}\text { MCP-1 (pg/mL): Controls } 460 \text { (IQR 376-617); Child A stage: } 305 \text { (IQR 139-365); } \\
\text { Child B: } 220 \text { (IQR 169-277) (p<0.05 vs. controls and Child A); } \\
\text { Child C: } 174 \text { (IQR 99-271) ( }<0.05 \text { vs. controls and Child A) } \\
\text { TNF- } \alpha \text { (pg/mL): Controls 3.9 (IQR 3.5-6.5) ); Child A stage: 5.6 (IQR 3.4-27.8); } \\
\text { Child B: } 5.0 \text { (IQR 2.8-33.2); Child C: 7.2 (IQR 4.2-16.8) } \\
\text { IL-6 (pg/mL): Controls 24.2 (IQR 1.2-43.1); Child A stage: 23.1 (IQR 8.9-78.2); } \\
\text { Child B: } 30.3 \text { (IQR 12.4-95.6); Child C: 35.8 (IQR 22.8-85.6) } \\
\text { IL-8 (pg/mL): Controls 18 (IQR 8-36) ); Child A stage: 50.3 (IQR 21.2-77.9); } \\
\text { Child B: } 49.0 \text { (IQR 14.3-80.2); Child C: 94.8 (IQR 46.2-261.4) } \\
\text { VEGF (pg/mL): Controls 265 (IQR 96-740) ); Child A stage: } 732 \text { (IQR 386-846); } \\
\text { Child B: } 405 \text { (IQR 97-716); Child C: 429 (IQR 249-599) } \\
\text { hsCRP (mg/L): Controls 1.6 (IQR 1.1-5.1) ); Child A stage: 3.6 (IQR 2.1-8.9); } \\
\text { Child B: 5.0 (IQR 1.4-7.0); Child C: 8.2 (IQR 7.3-12.8) ( } p<0.05 \text { vs. controls and Child B) }\end{array}$ \\
\hline [17] & $\begin{array}{l}24 \mathrm{AH} \text { patients ( } 5 \text { severe } \\
\text { and } 19 \text { non-severe disease), } \\
20 \text { healthy controls/plasma }\end{array}$ & $\begin{array}{l}\text { IL-6 (pg/mL): Controls }<7.8 \text {; Severe AH: } 504 \pm 681 \text {; Non-severe AH: } 25 \pm 32(p<0.001 \text { vs. severe AH }) \\
\text { IL-8 (pg/mL): Controls }<15.6 \text {; Severe AH: } 216 \pm 304 \text {; Non-severe AH: } 37 \pm 77(p<0.05 \text { vs. severe AH) } \\
\text { TNF- } \alpha(\mathrm{pg} / \mathrm{mL}) \text { : Controls }<15.6 ; \text {; Severe AH: } 29 \pm 18 ; \\
\text { Non-severe AH: } 17 \pm 6(p<0.005 \text { vs. severe AH })\end{array}$ \\
\hline [18] & $\begin{array}{l}33 \text { ALD cirrhosis, } 24 \\
\text { healthy controls/serum }\end{array}$ & $\begin{array}{l}\text { sTNF-R55 (pg/mL): Controls } 1.28 \pm 0.12 \text {; ALD: } 5.94 \pm 0.48(p<0.001) \\
\text { sIL-2R (pg/mL): Controls 545.33 } \pm 37.30 \text {; ALD: } 953.06 \pm 85.03(p<0.001)\end{array}$ \\
\hline [19] & $\begin{array}{l}94 \mathrm{ALD} \text { ( } 17 \text { steatosis, } 37 \mathrm{AH} \text {; } \\
40 \text { cirrhosis), } 35 \text { abstainers }\end{array}$ & IL-12 pg/mL: Controls $39.3 \pm 8.3$; Steatosis: $74.4 \pm 26.2 ;$ AH: $163.1 \pm 57.8$ \\
\hline [20] & $\begin{array}{l}24 \text { alcoholic patients; } \\
\text { hepatic mRNA expression }\end{array}$ & $\begin{array}{l}\text { TNF- } \alpha \text { : fibrosis }(\mathrm{F} 3 / \mathrm{F} 4) 1.74 \pm 0.27 ;(\mathrm{F} 0 / \mathrm{F} 1): 1 \pm 0.16(p=0.039) \\
\text { TGF- } \beta \text { : fibrosis }(\mathrm{F} 3 / \mathrm{F} 4) 2.33 \pm 0.17 ;(\mathrm{F} 0 / \mathrm{F} 1): 1 \pm 0.16(p=0.0001) \\
\text { Fas ligand: fibrosis }(\mathrm{F} 3 / \mathrm{F} 4) 1.55 \pm 0.13 ;(\mathrm{F} 0 / \mathrm{F} 1) ; 1.55 \pm 0.13(p=0.007)\end{array}$ \\
\hline [21] & $\begin{array}{l}43 \text { patients with ALD } \\
\text { cirrhosis ( } 29 \text { compensated } \\
\text { and } 14 \text { de-compensated), } \\
30 \text { healthy controls; } \\
\text { in plasma }\end{array}$ & $\begin{array}{l}\text { TNF- } \alpha(\mathrm{pg} / \mathrm{mL}) \text { : Controls } 46 \pm 10.0 \text {; cirrhosis } 30.2 \pm 2.10(p<0.05 v s . \text { control }) \text {; } \\
\text { De-compensated cirrhosis; } 24.5 \pm 1.9(p<0.05 v s . \text { control and } v s . \text { compensated }) \\
\text { IL-6 (pg/mL): Controls } 33.11 \pm 2.06 \text {; cirrhosis } 41.06 \pm 4.57(p<0.05 v s . \text { control): } \\
\text { De-compensated cirrhosis } 53.5 \pm 4.8(p<0.05 v s . \text { control and } v s . \text { compensated }) \\
\text { CRP (mg/L): Controls } 6.99 \pm 0.98 \text {; cirrhosis: } 20.07 \pm 13.90 \text { ( } p<0.05 v s . \text { control); } \\
\text { De-compensated cirrhosis: } 24.9 \pm 15.0(p<0.05 v s . \text { control })\end{array}$ \\
\hline
\end{tabular}

Fibrosis deposition is also influenced by the dysfunction of the wound-healing process in the liver [22]. A large sample of $260 \mathrm{AH}$ and 1180 hepatitis $\mathrm{C}$ virus (HCV) patients revealed that TNF- $\alpha$ levels were higher in ALD compared to $\operatorname{HCV}(p<0.05)$. Transforming growth factor (TGF)- $\beta$ levels were elevated in patients with more advanced fibrosis, regardless of the etiology of the liver disease [23]. A recent study compared the cytokines profile of 30 patients with alcoholic cirrhosis and 15 patients with HCV cirrhosis. IL-12, IL-6 and TNF- $\alpha$ levels were higher in alcoholic cirrhosis ( $p<0.05$ for all), while IL-1 $\beta$ and IL-10 levels were comparable between patients with alcoholic or HCV cirrhosis. TNF- $\alpha$ levels were elevated in ALD patients with cirrhosis compared to ALD patients without cirrhosis $(p<0.05)$. TNF- $\alpha$ levels were further elevated in ALD patients compared to non-alcoholic fatty liver disease (NAFLD) patients $(p<0.0001)$ [24].

Changes in cytokine levels were further analyzed in individuals undergoing alcohol withdrawal. Parameters of alcoholism, such as the pro-inflammatory cytokine IL-6, were found to decrease from 
baseline through day 15 in a small sample of 52 alcohol-dependent individuals without liver diseases undergoing alcohol detoxification [25].

Hepatic TGF- $\beta(p<0.001)$, TNF- $\alpha(p=0.034)$ and Fas ligand $(p=0.008)$ genes expression was correlated with fibrosis in a small sample of alcoholic patients [20]. Single-nucleotide polymorphisms in $I L-1 \beta(-511 \mathrm{C} / \mathrm{T}), I L-10(-592 \mathrm{C} / \mathrm{A}), T N F-\alpha(-308 \mathrm{G} / \mathrm{A},-238 \mathrm{G} / \mathrm{A}), T G F-\beta 1(-509 \mathrm{C} / \mathrm{T})$ and CTLA4 $(+49 \mathrm{~A} / \mathrm{G})$ were assessed in a South Indian population of 181 patients with alcoholic cirrhosis and 110 controls. Single-nucleotide polymorphisms associated with increased risk of ALD include the -238AA $T N F-\alpha$ variant [odds ratio (OR) $2.36,95 \%$ CI 1.1-5.3], $-511 \mathrm{C} \mathrm{IL-1 \beta}$ allele (OR 2.64, 95\% CI 1.2-5.9), -509C TGF- $\beta 1$ allele (OR 4.71, 95\% CI 1.7-13.1), and -592A IL-10 allele (OR 2.17, 95\% CI 1.1-4.8) [26]. There were no differences between genetic polymorphism at codon 10 in the TGF- $\beta$ gene and the development of alcoholic liver cirrhosis in a Korean population [27].

\section{Alcohol and Chemokines}

IL-8, a chemokine produced by a variety of cells including monocytes, macrophages, Kupffer cells and hepatocytes, can activate neutrophils. Peripheral neutrophilia and liver neutrophil infiltration are frequently noted in patients with ALD [2,28]. Patients with high serum IL-8 have a higher mortality rate than those with lower levels. Serum IL-8 levels decreased gradually with abstinence from alcohol [3].

A recent review by Gao and $\mathrm{Xu}$ [29] discusses several chemokines believed to play important roles in AH. These include several members of the CXC subfamily such as IL-8, Gro- $\alpha$, CXCL5, CXCL6, CXCL10, and platelet factor 4, whose levels were significantly elevated in AH livers compared with normal healthy control livers. Other molecules believed to play a role in AH include the pro-inflammatory cytokine IL-17 and the chemokines CXCL9 and CXCR3 [30]. Levels of the CC chemokine CCL2 (monocyte chemoattractant protein (MCP)-1), but not CCL5, were also elevated. Higher expression levels of IL-8, CXCL5, Gro- $\gamma$ and CXCL6 were associated with a less favorable prognosis in AH patients [31]. Many CXC and CC family members were markedly elevated in AH biopsy samples compared with healthy control liver samples in another study [32]. The levels of chemokines correlate with neutrophil infiltration and the severity of portal hypertension [31].

The hepatic and serum levels of CCL20 are also increased in AH. The interaction between CCL20 and CCR6 regulates liver inflammation, fibrosis and tumorigenesis [33]. In AH patients, CCL20 mRNA expression and serum levels positively correlated with one another, suggesting that the liver may be an important source of CCL20 [33]. A strong correlation was further observed between serum CCL20 and lipopolysaccharide (LPS) levels, the main inducer of this chemokine. Increased hepatic CCL20 expression and serum CCL20 levels correlated with short-term mortality (within 90 days of hospitalization) in AH patients [33].

Levels of pro-inflammatory factors (IL-6, CCL2, CCL5, IL-8, osteopontin, semaphorin 7A), inflammasome components (IL-1 $\beta$, IL-18, caspase-1), the total macrophage marker CD68 and fibrosis markers (TGF- $\beta 1$ ) were increased in liver tissue samples in ALD patients with severe liver damage compared to those with mild liver damage. A positive correlation was found between the mRNA expression of chemokines involved in the recruitment of immune cells such as osteopontin $(p<0.05)$, semaphorin 7A $(p<0.001)$ and IL-8 $(p=0.06)$, and severe steatosis $(\geq 33 \%)$ [34]. Alcohol withdrawal led to an increase in CCL18 expression $(p=0.001)$ in subcutaneous adipose tissue. Additionally, 
alcohol withdrawal was associated with decreased expression of the pro-inflammatory markers IL-18, CCL2, osteopontin and semaphorin 7A, and of the macrophage marker CD68 in subcutaneous adipose tissue by 1 week in patients with mild ALD, with an increase in the M2 marker CCL18 [34].

Higher serum osteopontin levels were observed in patients with more advanced hepatic inflammation $(p=0.047)$ and more advanced hepatic fibrosis $(p<0.001)$ in a sample of 204 heavy drinkers. Hepatic osteopontin expression correlated well with serum osteopontin levels, as well as with hepatic inflammation, fibrosis, TGF- $\beta$ expression and neutrophils accumulation among 72 heavy drinkers [35]. The hepatic expression of osteopontin was found to be greatly elevated among patients with $\mathrm{AH}$ compared to patients with hepatic diseases of other etiology or with healthy controls. Hepatic mRNA expression and serum osteopontin levels correlated with one another in AH patients, and with liver damage [36]. The presence of the CXCL1 rs4047 A allele was higher among patients with alcoholic cirrhosis (65.3\%) than among alcoholic controls (54.8\%) (OR $1.5595 \%$ CI 1.025-2.350 $p=0.04$ ) in a large sample of 458 patients with alcoholic cirrhosis (170 with HCC), 115 alcoholics without liver disease and 342 healthy controls. This allele was not associated with HCC development [37]. CXCL1 expression was further assessed among individuals carrying the CXCL1 rs4074 G/A polymorphism in a subsample of patients with high alcohol consumption (>300 g/week). The homozygous GG genotype in alcoholic patients was associated with CXCL1 expression similar to that of healthy controls. On the other hand, the presence of the A allele among patients with alcoholic cirrhosis was associated with significantly higher serum CXCL1 levels $[\mathrm{GA}=212.7 \pm 16.5(p=0.034)$ and AA $=287.9 \pm 73.3 \mathrm{pg} / \mathrm{mL}$ $(p=0.028)$ compared to the $\mathrm{GG}$ genotype, and $\mathrm{GA}=133.7 \pm 10.5(p=0.003)$ and $\mathrm{AA}=152.4 \pm 13.4 \mathrm{pg} / \mathrm{mL}$ $(p=0.03)$ compared to the corresponding genotypes in healthy controls] [37].

Hepatic gene expression profiling assessed by DNA microarray revealed that the expression of 207 genes was altered between 15 patients with severe $\mathrm{AH}$ (ABIC score $\geq 6.71$ points) and seven normal controls [32]. Some CC chemokines, particularly MCP-1, were up-regulated in AH patients compared to controls, while the expression profiles of others was similar. Some TNF superfamily receptors such as FAS, TRAILR1 and Fn14 were over-expressed in AH, while there was no difference in the expression profiles of TNF superfamily ligands such as TNF- $\alpha$ and Fas ligand between AH patients and controls. Hepatic gene expression of Fn14 (HR 1.05, 95\% CI 1.00-1.11, $p=0.03$ ), IL-8 (HR 1.14, 95\% CI 1.02-1.26, $p=0.019$ ), CXCL-5 (HR 1.01, 95\% CI 1.004-1.02, $p=0.006$ ), CXCL1 (HR 1.001, 95\% 1.00-1.003, $p=0.018$ ), and CXCL6 (HR 1.01, 95\% CI 1.004-1.03, $p=0.009$ ) predicted 90 day mortality in AH patients. Higher Fn14 hepatic expression predicted poorer 90-day survival rates. High Fn14 gene expression (>22-fold-expression) also predicted more severe portal hypertension $(p=0.04)$. The Fn14 gene expression profile was correlated with the ABIC score, an indicator of $\mathrm{AH}$ disease severity $(p=0.01)$. Fn14 protein expression was identified primarily in parenchymal cells around fibrogenic areas in $\mathrm{AH}$ patients. It was expressed in hepatocytes at the edge of regenerative nodules [32]. Higher mRNA expression of the M2 markers (CD206 and CD163) predicted limited hepatic injury in liver biopsies in alcohol drinkers. On the other hand, expression of IL-10 and of M1 markers (TNF- $\alpha$ ) predicted more severe hepatic injury [38].

Resistin was markedly increased in AH patients compared with cirrhotic controls in a sample of 76 patients with severe acute $\mathrm{AH}$ and 25 patients with alcoholic cirrhosis used as controls included in a prospective, case-control study. Elevated resistin levels predicted decreased survival rate. Platelet activation inhibitor-1 expression was mildly enhanced in AH subjects, while serum leptin levels were decreased in $\mathrm{AH}$ patients. Adiponectin and adipsin levels were similar between groups. Neither of platelet 
activation inhibitor-1, leptin, adiponectin or adipsin could be used to predict the 180-day survival rate. In contrast, all of TNF- $\alpha$, IL-6, IL-8, and IL-15 were significantly increased in patients with AH when compared to cirrhotic subjects, and all could be used to predict decreased survival rate [39].

\section{Alcoholic Hepatitis and Lipopolysaccharides}

Liver inflammation is collectively described by the elevated expression of pro-inflammatory genes, which is common to all liver conditions collectively referred to as hepatitis. Several central events are important in ALD, including bacterial translocation (the migration of bacteria and bacterial parts from the intestine to extra-intestinal organs), Toll-like receptor (TLR) stimulation by bacterial ligands, as well as intestinal bacterial overgrowth and dysbiosis [40]. Alcohol has been suggested to also alter the intestinal microbiota, and a correlation between dysbiosis and endotoxemia is believed to exist $[41,42]$.

Alcohol consumption is a known cause of increased gut permeability, facilitating the translocation of gut microbiota into the circulation. In turn, this leads to increased liver exposure to LPS, which causes liver injury via TLR4 activation [42]. Human TLR4 recognizes LPS via the co-receptors CD14 or MD-2. This recruits MyD88, forming a TLR4-MyD88 complex. This complex further activates nuclear factor NF- $\kappa$ B. This phenomenon leads to increased production of pro-inflammatory cytokines, such as TNF- $\alpha$, IL-6, and IL-1 $\beta[43,44]$.

Chronic alcohol consumption increases gut permeability, permitting the translocation of LPS from the intestinal lumen to the portal circulation. During AH, LPS interacts with host immune cells and triggers the release of pro-inflammatory cytokines. TLRs are important components of the innate immune system and recognize pathogenic toxins. TLR4 is particularly important in AH. Ultimately, the activation of this pathway leads to the recruitment of inflammatory cells [45]. Importantly, intestinal inflammation can result in disruption of epithelial tight junctions and bacterial translocation, and this, too, can play a significant role in ALD development [46,47]. A positive association is known to exist between the circulating levels of bacterial products in plasma and the severity of liver disease in patients, particularly liver disease of alcoholic etiology [40].

Increasing serum LPS levels paralleled increasing blood alcohol levels. Microbial translocation from the gut was shown through a significant increase in serum cytokine levels. This was observed through $24 \mathrm{~h}$. Significant induction of inflammatory cytokines such as TNF- $\alpha(p<0.05)$, IL-6 $(p<0.05)$ and MCP-1 $(p<0.05)$ ensued following treatment of whole blood samples with LPS levels comparable to those observed in healthy volunteers after binge drinking [10].

Elevated LPS levels were noted in patients with severe AH in one study, and this was closely related to elevated levels of pro-inflammatory cytokines [17,48]. LPS levels were comparable between alcoholics with or without liver disease, and they were significantly higher in both patient groups compared to healthy subjects $(p=0.001)$. Dysbiosis was observed with a higher incidence among alcoholics than among healthy subjects [49]. Markwick et al. [50] further observed impaired antibacterial innate and adaptive immune responses in patients with acute AH compared to patients with stable advanced alcohol-related cirrhosis or healthy controls.

Bacterial translocation is initiated when the intestinal epithelium gets damaged. For example, acetaldehyde, an alcohol metabolite, has the potential to damage the intestinal epithelium. In turn, bacterial products (pathogen-associated molecular patterns, which recognize conserved features of microbial products) such as LPS, flagellin, peptidoglycan, and bacterial DNA can be measured in portal circulation. Plasma LPS levels are elevated in chronic drinkers. The innate immune system 
recognizes bacterial products, and the result of the interaction between TLR4 and its agonist, LPS, is the production of pro-inflammatory cytokines and chemokines [40,42].

In a study conducted by Almeida and colleagues [51] there were lower levels of peripheral blood $\mathrm{CD}^{+} \mathrm{CD} 25^{\text {hi }} \mathrm{CD} 127^{-10}$ circulating regulatory $\mathrm{T}$ cells in $\mathrm{AH}$ patients than in chronic alcoholic patients without liver disease or healthy controls. T-cell proliferation rates were higher in AH. LPS-binding protein (LBP) levels were elevated in AH patients compared to controls (median $6.52 \mu \mathrm{g} / \mathrm{mL} v s$. median $2.47 \mu \mathrm{g} / \mathrm{mL}, p<0.005)$. Systemic inflammatory response syndrome was associated with elevated plasma LBP levels in AH patients. Increased secretion of pro-inflammatory cytokines was observed in AH patients despite a normal numbers of peripheral blood monocytes and all dendritic cells subsets.

A prospective study in $50 \mathrm{AH}$ patients and 46 controls (26 patients with stable alcoholic cirrhosis and 20 healthy individuals) followed for 30 days measured plasma levels of soluble CD163 and liver tissue expression of CD163 as a specific marker of inflammatory macrophage activation, and plasma LPS, sCD14, and LBP as key components of the LPS pathway. Plasma sCD163 levels were elevated in $\mathrm{AH}$ patients (mean $15.4 \mathrm{mg} / \mathrm{L}$ ) compared to alcoholic cirrhosis (mean $11.5 \mathrm{mg} / \mathrm{L} ; p<0.002$ ) and healthy individuals (mean $1.5 \mathrm{mg} / \mathrm{L} ; p<0.001$ ). LPS was detectable in peripheral venous blood in $48.0 \%$ of AH patients and only $15.0 \%$ of healthy controls. Plasma LBP was higher in AH patients (mean $29 \mu \mathrm{g} / \mathrm{mL}$ ) than in alcoholic cirrhosis (mean $17 \mu \mathrm{g} / \mathrm{mL} ; p<0.002$ ) and healthy controls (mean $15 \mu \mathrm{g} / \mathrm{mL} ; p<0.002$ ). Similarly, sCD14 was higher in AH patients (mean $2.4 \mu \mathrm{g} / \mathrm{mL}$ ) than in healthy controls (mean $1.3 \mu \mathrm{g} / \mathrm{mL} ; p<0.0001$ ), but it was similar in alcoholic cirrhosis (mean $2.4 \mu \mathrm{g} / \mathrm{mL}$ ). All of LPS, LBP, and sCD14 were shown to decline during the 30 day follow-up. These parameters did not predict the risk of infection. In contrast, higher SCD163 at study entry predicted mortality in AH patients (mean $21 \mathrm{mg} / \mathrm{L}$ among patients who died and mean $15 \mathrm{mg} / \mathrm{L}$ among patients who lived, $p<0.001)[52]$.

\section{Conclusions}

Clinical and pathological features of ALD that are mediated by cytokines, include cachexia, cholestasis, fibrosis, synthesis of acute-phase proteins, and hypergammaglobulinemia. Pro-inflammatory cytokines such as TNF- $\alpha$ and IL- 6 are mainly involved in cholestasis and the synthesis of acute-phase proteins. The pro-fibrogenic cytokine TGF- $\beta$, which is released by activated Kupffer cells and stellate cells, is the critical cytokine involved in fibrosis. In patients with progressive ALD, the balance between pro-inflammatory and anti-inflammatory cytokines may be shifted toward the pro-inflammatory axis, thus the counteracting anti-inflammatory cytokines are unable to control inflammation and fibrosis.

\section{Acknowledgments}

The article is based upon the some of the presentations given at the International Symposium "Alcoholic Liver Disease in Israel - The New Challenge" organized by M. G. Neuman, Y. Maor, E. Melzer and S. Malnick, January 2015, Kaplan Medical Center, Rehovot, Israel. The funding for the manuscript was provided by In Vitro Drug Safety and Biotechnology and Mahaffy Innovative Grant, Sunnybrook HSC.

\section{Conflicts of Interest}

The authors declare no conflict of interest. 


\section{Abbreviations}

$\begin{array}{ll}\text { ALD } & \text { alcoholic liver disease } \\ \text { AH } & \text { alcoholic hepatitis } \\ \text { CI } & \text { confidence interval } \\ \text { HCC } & \text { hepatocellular carcinoma } \\ \text { HCV } & \text { hepatitis C virus } \\ \text { HR } & \text { hazard ratio } \\ \text { hsCRP } & \text { high-sensitivity C-reactive protein } \\ \text { IL } & \text { interleukin } \\ \text { IFN } & \text { interferon } \\ \text { LBP } & \text { lipopolysaccharide-binding protein } \\ \text { LPS } & \text { lipopolysaccharide } \\ \text { OR } & \text { odds ratio } \\ \text { TGF } & \text { transforming growth factor } \\ \text { TLR } & \text { Toll-like receptor } \\ \text { TNF } & \text { tumor necrosis factor }\end{array}$

\section{References}

1. Zimmerman, H.J. The evolution of alcoholic cirrhosis. Med. Clin. N. Am. 1955, 39, 249-251.

2. Neuman, M.G. Cytokines and inflamed liver. Clin. Biochem. 1999, 33, 601-605.

3. Neuman, M.G. Mechanism of alcoholic liver disease. Clin. Biochem. 2001, 34, 163-167.

4. Neuman, M.G. Cytokines in alcoholic liver. Alcohol Res. Health 2003, 27, 307-316.

5. Ishak, K.G.; Zimmerman, H.J.; Ray, M.B. Alcoholic liver disease: Pathologic, pathogenetic and clinical aspects. Alcohol Clin. Exp. Res. 1991, 15, 45-66.

6. Lefkowitch, J.H. Morphology of alcoholic liver disease. Clin. Liver Dis. 2005, 9, 37-53.

7. O’Shea, R.S.; Dasarathy, S.; McCullough, A.J. Alcoholic liver disease. Hepatology 2010, 51, 307-28.

8. Pares, A.; Caballeria, J.; Bruguera, M.; Torres, M.; Rodes, J. Histologic course of alcoholic hepatitis: Influence of abstinence, sex and extent of hepatic damage. J. Hepatol. 1986, 2, 33-42.

9. Decker, K. Biologically active products of stimulated liver macrophages (Kupffer cells). Eur. J. Biochem. 1990, 192, 245-261.

10. Neuman, M.G.; French, S.W.; French, B.A.; Seitz, H.K.; Cohen, L.B.; Mueller, S.; Osna, N.A.; Kharbanda, K.K.; Seth, D.; Bautista, A.; et al. Alcoholic and nonalcoholic steatohepatitis. Exp. Mol. Pathol. 2014, 97, 492-510.

11. Umhau, J.C.; Schwandt, M.; Solomon, M.G.; Yuan, P.; Nugent, A.; Zarate, C.A.; Drevets, W.C.; Hall, S.D.; George, D.T.; Heilig, M. Cerebrospinal fluid monocyte chemoattractant protein-1 in alcoholics: Support for a neuroinflammatory model of chronic alcoholism. Alcohol Clin. Exp. Res. 2014, 38, 1301-1306.

12. Fuster, D.; Cheng, D.M.; Quinn, E.K.; Armah, K.A.; Saitz, R.; Freiberg, M.S.; Samet, J.H.; Tsui, J.I. Inflammatory cytokines and mortality in a cohort of HIV-infected adults with alcohol problems. AIDS 2014, 28, 1059-1064. 
13. Reiberger, T.; Ferlitsch, A.; Payer, B.A.; Mandorfer, M.; Heinisch, B.B.; Hayden, H.; Lammert, F.; Trauner, M.; Peck-Radosavljevic, M.; Vogelsang, H. Non-selective betablocker therapy decreases intestinal permeability and serum levels of LBP and IL-6 in patients with cirrhosis. J. Hepatol. 2013, 58, 911-921.

14. González-Reimers, E.; Santolaria-Fernández, F.; Medina-García, J.A.; González-Pérez, J.M.; de la Vega-Prieto, M.J.; Medina-Vega, L.; Martín-González, C.; Durán-Castellón, M.C. TH-1 and TH-2 cytokines in stable chronic alcoholics. Alcohol Alcohol. 2012, 47, 390-396.

15. González-Reimers, E.; Sánchez-Pérez, M.J.; Santolaria-Fernández, F.; Abreu-González, P.; de la Vega-Prieto, M.J.; Viña-Rodríguez, J.; Alemán-Valls, M.R.; Rodríguez-Gaspar, M. Changes in cytokine levels during admission and mortality in acute alcoholic hepatitis. Alcohol 2012, 46, 433-440.

16. Mortensen, C.; Andersen, O.; Krag, A.; Bendtsen, F.; Møller, S. High-sensitivity C-reactive protein levels predict survival and are related to haemodynamics in alcoholic cirrhosis. Eur. J. Gastroenterol. Hepatol. 2012, 24, 619-626.

17. Ishikawa, M.; Uemura, M.; Matsuyama, T.; Matsumoto, M.; Ishizashi, H.; Kato, S.; Morioka, C.; Fujimoto, M.; Kojima, H.; Yoshiji, H.; et al. Potential role of enhanced cytokinemia and plasma inhibitor on the decreased activity of plasma ADAMTS13 in patients with alcoholic hepatitis: Relationship to endotoxemia. Alcohol Clin. Exp. Res. 2010, 34, S25-S33.

18. Díez-Ruiz, A.; García-Saura, P.L.; García-Ruiz, P.; González-Calvin, J.L.; Gallego-Rojo, F.; Fuchs, D. Bone mineral density, bone turnover markers and cytokines in alcohol-induced cirrhosis. Alcohol Alcohol. 2010, 45, 427-430.

19. Tung, K.H.; Huang, Y.S.; Yang, K.C.; Perng, C.L.; Lin, H.C.; Lee, S.D. Serum interleukin-12 levels in alcoholic liver disease. J. Chin. Med. Assoc. 2010, 73, 67-71.

20. Lavallard, V.J.; Bonnafous, S.; Patouraux, S.; Saint-Paul, M.C.; Rousseau, D.; Anty, R.; le Marchand-Brustel, Y.; Tran, A.; Gual, P. Serum markers of hepatocyte death and apoptosis are non invasive biomarkers of severe fibrosis in patients with alcoholic liver disease. PLoS ONE 2011, 6, e17599.

21. Zuwała-Jagiełło, J.; Pazgan-Simon, M.; Simon, K.; Warwas, M. Advanced oxidation protein products and inflammatory markers in liver cirrhosis: A comparison between alcohol-related and HCV-related cirrhosis. Acta Biochim. Pol. 2011, 58, 59-65.

22. Friedman, S.L. Molecular regulation of hepatic fibrosis, and integrated cellular response to tissue injury. J. Biol. Chem. 2000, 275, 2247-2250.

23. Neuman, M.G.; Schmilovitz-Weiss, H.; Hilzenrat, N.; Bourliere, M.; Marcellin, P.; Trepo, C.; Mazulli, T.; Moussa, G.; Patel, A.; Baig, A.A.; et al. Markers of inflammation and fibrosis in alcoholic hepatitis and viral hepatitis C. Int. J. Hepatol. 2012, doi: 10.1155/2012/231210.

24. Sowa, J.P.; Atmaca, Ö.; Kahraman, A.; Schlattjan, M.; Lindner, M.; Sydor, S.; Scherbaum, N.; Lackner, K.; Gerken, G.; Heider, D.; et al. Non-invasive separation of alcoholic and non-alcoholic liver disease with predictive modeling. PLOS ONE 2014, 9, e101444.

25. Chatzipanagiotou, S.; Kalykaki, M.; Tzavellas, E.; Karaiskos, D.; Paparrigopoulos, T.; Liappas, A.; Nicolaou, C.; Michalopoulou, M.; Zoga, M.; Boufidou, F.; et al. Alteration of biological markers in alcohol-dependent individuals without liver disease during the detoxification therapy. In Vivo 2010, 24, 325-328.

26. Roy, N.; Mukhopadhyay, I.; Das, K.; Pandit, P.; Majumder, P.P.; Santra, A.; Datta, S.; Banerjee, S.; Chowdhury, A. Genetic variants of TNF $\alpha$, IL10, IL1 $\beta$, CTLA4 and TGF $\beta 1$ modulate the indices of alcohol-induced liver injury in East Indian population. Gene 2012, 509, 178-188. 
27. Lee, J.J.; Park, S.K.; Kwon, O.S.; Won, I.S.; Kim, D.K.; Jung, Y.K.; Ku, Y.S.; Kim, Y.S.; Choi, D.J.; Kim, J.H. Genetic polymorphism at codon 10 of the transforming growth factor- $\beta 1$ gene inpatients with alcoholic liver cirrhosis. Korean J. Hepatol. 2011, 17, 37-43.

28. McClain, C.J.; Hill, D.B.; Schmidt, J.; Diehl, A.M. Cytokines and alcoholic liver disease. Semin Liver Dis. 1993, 13, 170-182.

29. Gao, B.; Xu, M. Chemokines and alcoholic hepatitis: Are chemokines good therapeutic targets? Gut 2014, 63, 1683-1684.

30. Dhanda, A.D.; Lee, R.W.; Collins, P.L.; McCune, C.A. Molecular targets in the treatment of alcoholic hepatitis. World J. Gastroenterol. 2012, 18, 5504-5513.

31. Dominguez, M.; Miquel, R.; Colmenero, J.; Moreno, M.; García-Pagán, J.C.; Bosch, J.; Arroyo, V.; Ginès, P.; Caballería, J.; Bataller, R. Hepatic expression of CXC chemokines predicts portal hypertension and survival in patients with alcoholic hepatitis. Gastroenterology 2009, 136, 1639-1650.

32. Affò, S.; Dominguez, M.; Lozano, J.J.; Sancho-Bru, P.; Rodrigo-Torres, D.; Morales-Ibanez, O.; Moreno, M.; Millán, C.; Loaeza-del-Castillo, A.; Altamirano, J.; et al. Transcriptome analysis identifies TNF superfamily receptors as potential therapeutic targets in alcoholic hepatitis. Gut 2013, 62, 452-460.

33. Affò, S.; Morales-Ibanez, O.; Rodrigo-Torres, D.; Altamirano, J.; Blaya, D.; Dapito, D.H.; Millán, C.; Coll, M.; Caviglia, J.M.; Arroyo, V.; et al. CCL20 mediates lipopolysaccharide induced liver injury and is a potential driver of inflammation and fibrosis in alcoholic hepatitis. Gut 2014, 63, 1782-1792.

34. Voican, C.S.; Njiké-Nakseu, M.; Boujedidi, H.; Barri-Ova, N.; Bouchet-Delbos, L.; Agostini, H.; Maitre, S.; Prévot, S.; Cassard-Doulcier, A.M.; Naveau, S.; et al. Alcohol withdrawal alleviates adipose tissue inflammation in patients with alcoholic liver disease. Liver Int. 2015, 35, 967-978.

35. Patouraux, S.; Bonnafous, S.; Voican, C.S.; Anty, R.; Saint-Paul, M.C.; Rosenthal-Allieri, M.A.; Agostini, H.; Njike, M.; Barri-Ova, N.; Naveau, S.; et al. The osteopontin level in liver, adipose tissue and serum is correlated with fibrosis in patients with alcoholic liver disease. PLoS ONE 2012, 7, e35612.

36. Morales-Ibanez, O.; Domínguez, M.; Ki, S.H.; Marcos, M.; Chaves, J.F.; Nguyen-Khac, E.; Houchi, H.; Affò, S.; Sancho-Bru, P.; Altamirano, J.; et al. Human and experimental evidence supporting a role for osteopontin in alcoholic hepatitis. Hepatology 2013, 58, 1742-1756.

37. Nischalke, H.D.; Berger, C.; Lutz, P.; Langhans, B.; Wolter, F.; Eisenhardt, M.; Krämer, B.; Kokordelis, P.; Glässner, A.; Müller, T.; et al. Influence of the CXCL1 rs4074 A allele on alcohol induced cirrhosis and HCC inpatients of European descent. PLOS ONE 2013, 8, e80848.

38. Wan, J.; Benkdane, M.; Teixeira-Clerc, F.; Bonnafous, S.; Louvet, A.; Lafdil, F.; Pecker, F.; Tran, A.; Gual, P.; Mallat, A.; et al. M2 Kupffer cells promote M1 Kupffer cell apoptosis: A protective mechanism against alcoholic and nonalcoholic fatty liver disease. Hepatology 2014, 59, 130-142.

39. Rachakonda, V.; Gabbert, C.; Raina, A.; Li, H.; Malik, S.; DeLany, J.P.; Behari, J. Stratification of risk of death in severe acute alcoholic hepatitis using a panel of adipokines and cytokines. Alcohol Clin. Exp. Res. 2014, 38, 2712-2721.

40. Hartmann, P.; Chen, W.C.; Schnabl, B. The intestinal microbiome and the leaky gut as therapeutic targets in alcoholic liver disease. Front. Physiol. 2012, doi:10.3389/fphys.2012.00402. 
41. Bode, C.; Bode, J.C. Activation of the innate immune system and alcoholic liver disease: Effects of ethanol per se or enhanced intestinal translocation of bacterial toxins induced by ethanol? Alcohol Clin. Exp. Res. 2005, 29, S166-S171.

42. Chassaing, B.; Etienne-Mesmin, L.; Gewirtz, A.T. Microbiota-liver axis in hepatic disease. Hepatology 2014, 59, 328-339.

43. Da Silva Correia, J.; Soldau, K.; Christen, U.; Tobias, P.S.; Ulevitch, R.J. Lipopolysaccharide is in close proximity to each of the proteins in its membrane receptor complex. Transfer from CD14 to TLR4 and MD-2. J. Biol. Chem. 2001, 276, 21129-21135.

44. Kawai, T.; Takeuchi, O.; Fujita, T.; Inoue, J.; Mühlradt, P.F.; Sato, S.; Hoshino, K.; Akira, S. Lipopolysaccharide stimulates the MyD88-independent pathway and results in activation of IFN-regulatory factor 3 and the expression of a subset of lipopolysaccharide-inducible genes. J. Immunol. 2001, 167, 5887-5894.

45. Jampana, S.C.; Khan, R. Pathogenesis of alcoholic hepatitis: Role of inflammatory signaling and oxidative stress. World J. Hepatol. 2011, 3, 114-117.

46. Chen, P.; Stärkel, P.; Turner, J.R.; Ho, S.B.; Schnabl, B. Dysbiosis-induced intestinal inflammation activates tumor necrosis factor receptor I and mediates alcoholic liver disease in mice. Hepatology 2015, 61, 883-894.

47. Barve, S.; Kirpich, I.A.; McClain, C.J. Tumor necrosis factor alpha-induced receptor 1 signaling in alcoholic liver disease: A gut reaction? Hepatology 2015, 61, 754-756.

48. Ceccarelli, S.; Nobili, V.; Alisi, A. Toll-like receptor-mediated signaling cascade as a regulator of the inflammation network during alcoholic liver disease. World J. Gastroenterol. 2014, 20, 16443-16451.

49. Mutlu, E.A.; Gillevet, P.M.; Rangwala, H.; Sikaroodi, M.; Naqvi, A.; Engen, P.A.; Kwasny, M.; Lau, C.K.; Keshavarzian, A. Colonic microbiome is altered in alcoholism. Am. J. Physiol. Gastrointest Liver Physiol. 2012, 302, G966-G978.

50. Markwick, L.J.; Riva, A.; Ryan, J.M.; Cooksley, H.; Palma, E.; Tranah, T.H.; Manakkat Vijay, G.K.; Vergis, N.; Thursz, M.; Evans, A.; et al. Blockade of PD1 and TIM3 restores innate and adaptive immunity in patients with acute alcoholic hepatitis. Gastroenterology 2015, 148, 590-602.

51. Almeida, J.; Polvorosa, M.A.; Gonzalez-Quintela, A.; Marcos, M.; Pastor, I.; Cerceño, M.L.H.; Orfao, A.; Laso, F.J. Decreased peripheral blood CD4+/CD25+ regulatory T cells in patients with alcoholic hepatitis. Alcohol Clin. Exp. Res. 2013, 37, 1361-1369.

52. Sandahl, T.D.; Grønbaek, H.; Møller, H.J.; Støy, S.; Thomsen, K.L.; Dige, A.K.; Agnholt, J.; Hamilton-Dutoit, S.; Thiel, S.; Vilstrup, H. Hepatic macrophage activation and the LPS pathway in patients with alcoholic hepatitis: A prospective cohort study. Am. J. Gastroenterol. 2014, 109, 1749-1756.

(C) 2015 by the authors; licensee MDPI, Basel, Switzerland. This article is an open access article distributed under the terms and conditions of the Creative Commons Attribution license (http://creativecommons.org/licenses/by/4.0/). 